\title{
Soybean Milk-Based Extender for Cryopreservation of Buck Spermatozoa
}

\author{
Soltan, Waleed \\ Biotechnology Research Department, Animal Production Research Institute, Agriculture Research \\ Center | Laboratory of Reproductive Physiology and Biotechnology, Department of Animal and \\ Marine Bioresource Sciences, Faculty of Agriculture, Kyushu University
}

\section{El-Siefy, El-Shenawy}

Biotechnology Research Department, Animal Production Research Institute, Agriculture Research Center | Laboratory of Reproductive Physiology and Biotechnology, Department of Animal and Marine Bioresource Sciences, Faculty of Agriculture, Kyushu University

\section{Abe El-Razek, Ibrahim}

Animal Production Department, Faculty of Agriculture, Kafr El-Sheikh University | Laboratory of Reproductive Physiology and Biotechnology, Department of Animal and Marine Bioresource Sciences, Faculty of Agriculture, Kyushu University

\section{El-Sharawy, Mohamed}

Animal Production Department, Faculty of Agriculture, Kafr El-Sheikh University | Department of Animal and Marine Bioresource Sciences, Graduate School, Kyushu University I Laboratory of Reproductive Physiology and Biotechnology, Department of Animal and Marine Bioresource Sciences, Faculty of Agriculture, Kyushu University

他

https://doi.org/10.5109/1854007

出版情報：九州大学大学院農学研究院紀要. 62 (2)，pp.361-366，2017-09-08. Faculty of Agriculture, Kyushu University

バージョン :

権利関係 : 


\title{
Soybean Milk-Based Extender for Cryopreservation of Buck Spermatozoa
}

\section{Waleed SOLTAN ${ }^{1}$, El-Shenawy EL-SIEFY ${ }^{1}$, Ibrahim ABD EL-RAZEK ${ }^{2}$, Mohamed EL-SHARAWY', , Kaiyu KUBOTA ${ }^{3}$, Nobuhiko YAMAUCHI ${ }^{4}$ and Ibrahim EL-SHAMAA ${ }^{2 *}$}

\author{
Laboratory of Reproductive Physiology and Biotechnology, Department of Animal and Marine Bioresource Sciences, \\ Faculty of Agriculture, Kyushu University, Fukuoka 812-8581, Japan \\ (Received April 28, 2017 and accepted May 10, 2017)
}

\begin{abstract}
The aim of this study was to investigate incorporating whole soybean milk instead of the traditional egg yolk in goat semen extender. The semen ejaculates were collected from three fertile bucks, aged 2-3 years using artificial vagina. Collected semen was divided into 6 parts; the first was diluted with Tris-egg yolk extender (TEY) saved as control, while the others were diluted with Tris- soybean milk extender (TSM) at levels of 5, 10, 15, 20 and 25\%. Pooled ejaculates were further processed for freezing using $0.25 \mathrm{ml}$ French straws. Diluted semen at a rate of $1: 4$ was placed into a refrigerator at $5^{\circ} \mathrm{C}$ for $4 \mathrm{~h}$ as equilibration period. At the end of equilibration period, extended semen was packaged in straws and stored at $-196^{\circ} \mathrm{C}$. Then after, frozen semen was thawed by dipping the straws into a water bath at $37^{\circ} \mathrm{C}$ for $30 \mathrm{sec}-$ onds. Percentages of sperm motility, live spermatozoa, sperm abnormalities and recovery rate were determined. The results revealed that there were significant differences $(P<0.05)$ in buck sperm characteristics (percentages of sperm motility, live spermatozoa, sperm abnormalities and plasma membrane and acrosome integrity) among post-dilution, post equilibration and post thawing processes. Addition of $15 \%$ of soybean milk led to a significant $(P<0.05)$ improvement of sperm motility, live spermatozoa, sperm abnormalities and plasma membrane and acrosome integrity of buck spermatozoa during different stages of cryopreservation compared to control, while the lowest values were recorded at a level of $25 \%$ soybean milk extender. On the basis of our results, we concluded that soybean milk-based extender at the rate of $15 \%$ of soybean milk has the potential to maintain buck sperm quality after freezing -thawing process compared with cryopreservation in a traditional protection extender (egg yolk).
\end{abstract}

Key words: Buck Semen, Cryopreservation, Extender, Soybean Milk

\section{INTRODUCTION}

The artificial insemination (AI) in goats is biotechnological method providing augmentation of the genetic merit in goat flocks (Leboeuf et al., 2000). Successful preservation of superior male sperm will give the chance for future recalling even in the absence of those males. Egg yolk is a major constituent of extenders used for storage and cryopreservation of semen of domestic animals including bull, ram, goat and pig. The main advantage of egg yolk extender is the fraction of low density lipoprotein which protects the sperm phospholipids during cryopreservation (Amirat et al., 2005). However, wide variations in the constituents of egg yolk make the beneficial effect difficult to assess (Gil et al., 2003; Amirat et al., 2005). Moreover, the fertilizing capacity of spermatozoa is negatively affected by the risk of microbial contamination associated with egg yolk (Bousseau et al., 1998; Aires et al., 2003). It has also been reported that the fat globules of egg yolk make the evaluation of sperm difficult (Singh et al., 2012). These circumstances demand

Biotechnology Research Department, Animal Production Research Institute, Agriculture Research Center, Egypt

Animal Production Department, Faculty of Agriculture, Kafr El-Sheikh University, 33516, Egypt

Hitachi City Community Obstetrics and Gynecology, Tokyo Medical University, Shinjuku-ku 160-0023, Tokyo

${ }^{4}$ Department of Animal and Marine Bioresource Sciences, Graduate School, Kyushu University, Fukuoka 812-0023, Japan

* Correspondence author (E-mail: elshamaa2008@yahoo.com) for the partial or complete replacement of egg yolk with lecithin derived from plant source such as soybeans for the preservation of animal semen. Currently, egg and milk based extenders are extensively used for semen extension and storage of different animal species (Kasimanickam et al., 2011; Khan et al., 2012). Also, vegetable origin extenders are in vogue which is considered to be alternative to milk or yolk based extenders (Gil et al., 2003). According to Aires et al. (2003) soy lecithin-based extender is superior to egg yolk-based extender for bovine and ram semen. In addition, ElKeraby et al. (2010) found that replacing whole soybean milk for traditional egg yolk increased sperm motility and decreased bacterial count in post- thawed bovine semen extender. So the search for non-animal origin, well defined and contamination free medium for the extension of semen is highly desired (Ansari et al., 2013). Singh et al. (2012) observed that $25 \%$ soya based extender produced better motility, viability, membrane and acrosome integrity of bovine sperm at $5^{\circ} \mathrm{C}$ at different time interval. In buffalo bulls, El-Keraby et al. (2013) recoded a significant increase in the post-thaw sperm motility in frozen semen diluted with $10 \%$ soybean milk (SBM) compared with frozen semen diluted with 20\% egg yolk extender (EY), the conception rates in buffalo cows inseminated with frozen thawed semen containing 10\% SBM and EY were 66.1 and 54\%, respectively. In Holstein bulls, El-Siefy (2014) recoded a significant increase in post-thaw progressive motility, viability, plasma membrane and acrosome integrity in frozen semen diluted with $7 \%$ soybean milk (SBM) compared 
with frozen semen diluted with $20 \%$ egg yolk extender $(\mathrm{EY})$, the high fertility rate was recorded in cows inseminated with frozen thawed semen containing 7\% SBM and EY were 68.3 and $61.8 \%$, respectively.

Therefore, the present study was planned to investigate the impact of using different concentrations of whole soybean milk instead of traditional egg yolk on cryopreservation of frozen buck spermatozoa.

\section{MATERIALS AND METHODS}

\section{Experimental animals}

The present study was conducted at El-Karada Experimental Farm belonging to Animal Production Research Institute (APRI), Ministry of Agriculture, Egypt. Three sexually mature Baladi buck's male aged 2-3 years and weighed 60 kilograms in average were used in the current study for eight months (December 2015 to July 2016). All bucks were healthy and clinically free of internal and external parasites. The animals were kept under natural photoperiod and balanced nutritional status. The rations offered to bucks adjusted to meet their requirements during breeding season according to NRC (2007). Fresh water was available during the experimental period.

\section{Preparation of soybean milk}

The soybean milk was prepared according to the method described by El-Keraby et al. (2010). Briefly, a total of 10 grams of soybean grains was washed, soaked in $100 \mathrm{ml}$ distilled water and boiled for $30 \mathrm{~min}$. After boiling, the water was discarded, the whole soybean grains washed again and finally cooled down with $50 \mathrm{ml}$ distilled water containing $0.25 \%$ NaHCO3. The soybean grains were then grounded in a blender for 5 min and the slurry cooled. Soybean milk was extracted by filtration through a clean cotton cloth, centrifuged and boiled again for 10 minutes. The slurry was allowed again to cool down. Then, antibiotics were added at the rate of $0.25 \mathrm{~g}$ Lincospectin and $0.005 \mathrm{~g}$ Streptomycin $/ 100 \mathrm{ml}$ of the slurry. After that, the SBM extender was ready for use.

\section{Semen evaluation}

Following sexual preparation, semen was collected twice weekly by artificial vagina from three bucks for eight months (December 2015 to July 2016). Palpation of the external genitalia showed that they were typically normal. The testicular tone was glandular, almost equal in size and moved freely up and down within the scrotal pouches.

Immediately after semen collection, ejaculates were held in a water bath at $37^{\circ} \mathrm{C}$ until evaluated. Ejaculates having good mass motility (more than 75\%) were used and pooled. On each collection day, semen was divided into 6 parts; the first was diluted with Tris-egg yolk extender (control), while the others were diluted with Tris-soy milk extender at levels of 5, 10, 15, 20 and 25\% soybean milk.

Tris-egg yolk extender consisted of $3.07 \mathrm{~g}$ Tris (hydroxymethyl amino methane), $1.64 \mathrm{~g}$ citric acid, $1.26 \mathrm{~g}$ fructose, $15 \mathrm{ml}$ egg yolk, $5 \mathrm{ml}$ glycerol, $0.05 \mathrm{~g}$ streptomycin, $0.25 \mathrm{~g}$ lincospectin and completed with bi-distilled water up to $100 \mathrm{ml}$ (control). While, Tris- soybean milk extender consisted of $3.07 \mathrm{~g}$ Tris, $1.64 \mathrm{~g}$ citric acid, $1.26 \mathrm{~g}$ fructose, $5,7,10,15$ or $20 \mathrm{ml}$ soybean milk, $5 \mathrm{ml}$ glycerol, $0.05 \mathrm{~g}$ streptomycin, $0.25 \mathrm{~g}$ lincospectin and completed with bi-distilled water up to $100 \mathrm{ml}$.

\section{Semen processing}

Good ejaculates were further processed for freezing using $0.25 \mathrm{ml}$ French straws containing about $100 \times 10^{6}$ motile sperm before freezing. The dilution rate was 1:4. The Tris-egg yolk and Tris- soybean milk extenders were gently mixed and warmed up to $37^{\circ} \mathrm{C}$ in a water bath during semen extension. Vials containing the extended semen were placed in a water bath at $37^{\circ} \mathrm{C}$ and cooled gradually in a refrigerator at $5^{\circ} \mathrm{C}$ for 4 hours as an equilibration period.

At the end of equilibration period, the extended semen was loaded in $0.25 \mathrm{ml}$ French straws. During packaging in straws, extended semen was kept in an ice water bath at $5^{\circ} \mathrm{C}$. Straws were transferred into a processing canister and located horizontally in static nitrogen vapor $4 \mathrm{~cm}$ above the surface of liquid nitrogen for 10 minutes. The straws were then placed vertically in a metal canister and immersed completely in liquid nitrogen container for storage at $-196^{\circ} \mathrm{C}$. Freezing process was recorded as the method described by Salisbury et al. (1978). For thawing, straws were dipped into a water bath at $37^{\circ} \mathrm{C}$ for 30 seconds.

The sperm progressive motility was determined according to Melrose and Laing, (1970), live and abnormal spermatozoa were evaluated using eosin negrosin mixture prepared as described by Hancock, (1951), plasma membrane integrity of spermatozoa was according to Jeyendran et al. (1984) and acrosome integrity was assessed using Geimsa stain according to Watson (1975) in post-diluted, post-equilibrated and postthawed semen.

\section{Statistical Analysis}

Data were statistically analyzed using a statistical software (SPSS, version 18.0). One-way analysis of variance was used to test the significance of extenders on the studied traits (Steel et al., 1997). Means of the significantly affected traits were separated by Duncan Multiple Range Test (Duncan, 1955).

\section{RESULTS}

\section{Sperm progressive motility}

The effect of different levels of soybean milk addition on progressive sperm motility after dilution, equilibration and post-thawing were presented in Table 1 . Sperm motility percentages were significantly $(P<0.05)$ improved by 15 and $20 \%$ soybean milk extenders while high and low levels of soybean extenders decreased progressive motility compared to control. The superior percentages of sperm motility after dilution, equilibration and freeze-thawing processes were recorded in semen 
Table 1. Effect of different soybean milk concentrations on progressive motility (\%) of buck spermatozoa during different stages of cryopreservation (Mean \pm S.E)

\begin{tabular}{lcccccc}
\hline \multirow{2}{*}{$\begin{array}{c}\text { Cryopreservation } \\
\text { Stages }\end{array}$} & $\begin{array}{c}\text { Control } \\
\text { (EY 15\%) }\end{array}$ & 5 & 10 & 15 & 20 & 25 \\
\cline { 3 - 7 } & $66.2^{\mathrm{b}} \pm 0.66$ & $58.6^{\mathrm{c}} \pm 1.20$ & $66.0^{\mathrm{b}} \pm 0.81$ & $69.7^{\mathrm{a}} \pm 0.76$ & $67.7^{\mathrm{ab}} \pm 0.99$ & $55.2^{\mathrm{d}} \pm 1.16$ \\
Post-dilution & $49.8^{\mathrm{b}} \pm 1.01$ & $39.5^{\mathrm{c}} \pm 1.53$ & $50.2^{\mathrm{b}} \pm 1.25$ & $54.8^{\mathrm{a}} \pm 1.14$ & $51.7^{\mathrm{ab}} \pm 1.35$ & $37.9^{\mathrm{c}} \pm 1.84$ \\
Post-equilibration at $5^{\circ} \mathrm{C}$ & $27.4^{\mathrm{bc}} \pm 1.08$ & $11.6^{\mathrm{d}} \pm 0.62$ & $25.4^{\mathrm{c}} \pm 1.08$ & $32.6^{\mathrm{a}} \pm 1.29$ & $30.0^{\mathrm{ab}} \pm 0.98$ & $12.6^{\mathrm{d}} \pm 1.18$ \\
Post-thawing & & &
\end{tabular}

EY: Egg Yolk.

a, b, c and d: the different superscripts in the same row are significant at $(P<0.05)$.

extended with $15 \%$ soybean milk extender. The lowestsperm motility percentages were recorded in extenders containing 5, 10 and 25\% soybean milk compared to Tris egg yolk extender.

\section{Live sperm}

The results in Table 2., indicated that after dilution, after equilibration and post-thawing processes there are a significant effect $(P<0.05)$ on live sperm percentage. The highest live sperm percentage was obtained when semen was extended with $15 \%$ soybean milk, while the levels of 5, 10 and 25\% soybean milk extenders showed the lowest live sperm percentage compared to control. The results indicated that live sperm percentages were improved up to $20 \%$ level of soybean milk (Table 2).

\section{Sperm abnormalities}

Sperm abnormalities after different stages of cryopreservation were significantly $(P<0.05)$ lower in semen extended with $15 \%$ soybean milk as compared to control and other levels of soybean milk extenders (Table 3).

\section{Acrosome integrity}

After dilution, Post equilibration and post frozen thawed processes the percentages of buck acrosome integrity in 10, 15 and 20\% soybean extenders were higher than acrosome integrity in control extender, but the low and high (5 and 25\%) levels of soy bean extenders were significantly $(P<0.05)$ lower than control and other soybean extenders (Table 4 ).

\section{Plasma membrane integrity}

There were significant differences among different extenders on plasma membrane integrity. After dilution, the best plasma membrane integrity percentages were recorded in $15 \%$ soybean milk extender followed by 20 and $10 \%$ soybean extenders, while this membrane integrity was lower in high and low (25 and 5\%) soybean extender when compared to control (Table 5).

After equilibration process the percentage of plasma

Table 2. Effect of different soybean milk concentrations on live sperm (\%) of buck spermatozoa during different stages of cryopreservation (Mean \pm S.E)

\begin{tabular}{lcccccc}
\hline \multirow{2}{*}{$\begin{array}{c}\text { Cryopreservation } \\
\text { Stages }\end{array}$} & $\begin{array}{c}\text { Control } \\
\text { (EY 15\%) }\end{array}$ & \multicolumn{5}{c}{ Soybean concentration\% } \\
\cline { 3 - 7 } & $74.6^{\mathrm{b}} \pm 0.72$ & $66.5^{\mathrm{c}} \pm 1.10$ & $72.96^{\mathrm{b}} \pm 0.70$ & $77.7^{\mathrm{a}} \pm 0.66$ & $74.4^{\mathrm{b}} \pm 0.76$ & $63.6^{\mathrm{d}} \pm 1.03$ \\
\hline Post-dilution & $59.8^{\mathrm{b}} \pm 1.21$ & $47.5^{\mathrm{c}} \pm 1.03$ & $59.1^{\mathrm{b}} \pm 1.44$ & $63.5^{\mathrm{a}} \pm 1.19$ & $59.7^{\mathrm{b}} \pm 1.33$ & $44.7^{\mathrm{c}} \pm 1.48$ \\
Post-equilibration at $5^{\circ} \mathrm{C}$ & $38.5^{\mathrm{b}} \pm 1.38$ & $18.3^{\mathrm{c}} \pm 1.20$ & $34.8^{\mathrm{b}} \pm 1.43$ & $44.3^{\mathrm{a}} \pm 1.69$ & $38.8^{\mathrm{b}} \pm 1.14$ & $18.8^{\mathrm{c}} \pm 1.43$ \\
Post-thawing & & & & &
\end{tabular}

EY: Egg Yolk.

a, b, c and d: the different superscripts in the same row are significant at $(P<0.05)$.

Table 3. Effect of different soybean milk concentrations on abnormal sperm (\%) of buck spermatozoa during different stages of cryopreservation (Mean \pm S.E)

\begin{tabular}{|c|c|c|c|c|c|c|}
\hline \multirow{2}{*}{$\begin{array}{c}\text { Cryopreservation } \\
\text { Stages }\end{array}$} & \multirow{2}{*}{$\begin{array}{c}\text { Control } \\
(\mathrm{EY} 15 \%)\end{array}$} & \multicolumn{5}{|c|}{ Soybean concentration\% } \\
\hline & & 5 & 10 & 15 & 20 & 25 \\
\hline Post-dilution & $7.5^{\mathrm{bc}} \pm 0.11$ & $8.2^{\mathrm{ab}} \pm 0.19$ & $7.5^{\mathrm{bc}} \pm 022$ & $7.2^{\mathrm{c}} \pm 0.21$ & $8.0^{\mathrm{ab}} \pm 0.74$ & $8.5^{\mathrm{a}} \pm 0.38$ \\
\hline Post-equilibration at $5^{\circ} \mathrm{C}$ & $8.4^{\mathrm{ab}} \pm 0.19$ & $8.9^{\mathrm{a}} \pm 0.25$ & $7.9^{\mathrm{b}} \pm 0.21$ & $7.8^{\mathrm{b}} \pm 0.28$ & $8.2^{\mathrm{ab}} \pm 0.26$ & $8.9^{\mathrm{a}} \pm 0.45$ \\
\hline Post-thawing & $8.9^{\mathrm{bc}} \pm 0.20$ & $9.7^{\mathrm{ab}} \pm 0.28$ & $8.9^{\text {bc }} \pm 0.25$ & $8.2^{\mathrm{c}} \pm 0.26$ & $8.9^{\mathrm{bc}} \pm 0.32$ & $10.6^{\mathrm{a}} \pm 0.54$ \\
\hline
\end{tabular}

EY: Egg Yolk

a, b and c: the different superscripts in the same row are significant at $(P<0.05)$. 
Table 4. Effect of different soya bean milk concentrations on intact acrosome (\%) of buck spermatozoa during different stages of cryopreservation (Mean \pm S.E)

\begin{tabular}{lcccccc}
\hline \multirow{2}{*}{$\begin{array}{c}\text { Cryopreservation } \\
\text { Stages }\end{array}$} & $\begin{array}{c}\text { Control } \\
\text { (EY 15\%) }\end{array}$ & \multicolumn{5}{c}{ Soybean concentration\% } \\
\cline { 3 - 7 } & & 5 & 10 & 15 & 20 & 25 \\
\hline Post-dilution & $83.9^{\mathrm{a}} \pm 1.03$ & $77.0^{\mathrm{b}} \pm 1.54$ & $84.9^{\mathrm{a}} \pm 0.72$ & $85.9^{\mathrm{a}} \pm 0.08$ & $85.0^{\mathrm{a}} \pm 0.66$ & $77.0^{\mathrm{b}} \pm 1.41$ \\
Post-equilibration at $5^{\circ} \mathrm{C}$ & $74.6^{\mathrm{a}} \pm 1.22$ & $67.8^{\mathrm{b}} \pm 1.88$ & $77.0^{\mathrm{a}} \pm 1.06$ & $76.3^{\mathrm{a}} \pm 0.91$ & $76.3^{\mathrm{a}} \pm 0.96$ & $66.3^{\mathrm{b}} \pm 1.67$ \\
Post-thawing & $62.1^{\mathrm{b}} \pm 1.45$ & $48.8^{\mathrm{c}} \pm 2.21$ & $65.1^{\mathrm{ab}} \pm 1.33$ & $67.6^{\mathrm{a}} \pm 0.99$ & $65.5^{\mathrm{ab}} \pm 1.16$ & $46.2^{\mathrm{c}} \pm 2.46$ \\
\hline
\end{tabular}

EY: Egg Yolk.

$\mathrm{a}, \mathrm{b}$ and $\mathrm{c}$ : the different superscripts in the same row are significant at $(P<0.05)$.

Table 5. Effect of different soybean milk concentrations on plasma membrane integrity (\%) of buck spermatozoa during different stages of cryopreservation (Mean \pm S.E)

\begin{tabular}{lcccccc}
\hline \multirow{2}{*}{$\begin{array}{c}\text { Cryopreservation } \\
\text { Stages }\end{array}$} & $\begin{array}{c}\text { Control } \\
\text { (EY 15\%) }\end{array}$ & 5 & 10 & 15 & 20 & 25 \\
\cline { 3 - 7 } & $73.9^{\mathrm{b}} \pm 0.88$ & $68.9^{\mathrm{c}} \pm 1.19$ & $76.0^{\mathrm{ab}} \pm 0.74$ & $78.0^{\mathrm{a}} \pm 0.81$ & $76.8^{\mathrm{ab}} \pm 0.99$ & $68.7^{\mathrm{c}} \pm 1.42$ \\
Post-dilution & $65.0^{\mathrm{a}} \pm 1.17$ & $58.0^{\mathrm{b}} \pm 2.00$ & $65.8^{\mathrm{a}} \pm 1.48$ & $69.0^{\mathrm{a}} \pm 1.04$ & $66.2^{\mathrm{a}} \pm 1.52$ & $57.0^{\mathrm{b}} \pm 2.03$ \\
Post-equilibration at $5^{\circ} \mathrm{C}$ & $54.7^{\mathrm{a}} \pm 1.53$ & $42.8^{\mathrm{b}} \pm 2.84$ & $55.6^{\mathrm{a}} \pm 1.63$ & $58.9^{\mathrm{a}} \pm 1.45$ & $55.5^{\mathrm{a}} \pm 1.37$ & $36.7^{\mathrm{c}} \pm 2.97$ \\
Post-thawing & & & & &
\end{tabular}

EY: Egg Yolk.

a, b and c: the different superscripts in the same row are significant at $(P<0.05)$.

membrane integrity was higher in all soybean extenders compared to the control but differences were only significant among 10, 15 and 20\% soybean extenders and the other soybean extenders and control. After freezing - thawing process the percentage of plasma membrane integrity is significantly $(P<0.05)$ higher in $15 \%$ soybean extender followed by 10 and $20 \%$ soybean extenders, while the lowest value was recorded in 5\% soybean extenders.

\section{DISCUSSION}

Egg yolk is reported to have cryoprotectant antagonists, inconsistent composition, high-density lipoproteins (HDLs) and egg yolk granules that interfere with sperm motility (Ansari et al., 2010). Also, bacteriological property (Bousseau et al., 1998) and variable nature of egg yolk (Moussa et al., 2002) are not desirable. Egg yolk is routinely used as a non-permeable cryoprotectant for tris-based extenders, which provide protection against thermal shock and preserve sperm motility, and maintains acrosomal as well as mitochondrial integrity (Moustacas et al., 2011). Although egg yolk has cryoprotectant abilities, the deterrents associated with its use in semen extenders are of particular concern in present epoch.

The component of egg yolk, which gives protection to sperm membrane (phospholipids) integrity during cryopreservation, is the low-density lipoproteins (LDLs) known as lecithin (Moussa et al., 2002, Amirat et al., 2004, Andrabi et al., 2008 and El-Sharawy et al., 2012a, b). Soybean contains large proportion of low-density lipoproteins called soyalecithin similar to egg yolk leci- thin indicating its membrane protecting potential. This was evident after storage of bull semen after thawing of frozen semen which demonstrated that replacement of egg yolk with soya milk-based extender does not show any significant decline in semen characteristics but increase all evaluated parameters. Also, finish product of soya milk is autoclavable hence contain low risk of contamination. In this study, the quality of frozen buck semen preserved with TSM (Tris- soybean milk) diluents was superior to that preserved with TEY (Tris-egg yolk).

These all postulates may explain the high post-thaw progressive motility of buck spermatozoa in semen diluted with $15 \%$ soybean milk extender compared with whole EY control extender. These results are in agreement with those of El-Keraby et al. (2010); El-Siefy, (2014) who observed that the use TSM significantly $(P<0.05)$ increased the post-thaw sperm motility and pregnancy rate in Holstein bull semen. Also, Rehman et al. (2014) concluded that $25 \%$ soy extender could be used as a substitute of conventional egg yolk-based extender for bull semen stored at $4^{\circ} \mathrm{C}$. In buffalo the level of $10 \%$ TSM significantly $(P<0.01)$ improved the post-thaw sperm motility, live sperm, sperm abnormality and pregnancy rate (El-Keraby et al., 2013).

The beneficial effect of using lecithin base extender has been reported by several authors; (Van Wagtendonk et al., 2000, Thun et al., 2002, Aires et al., 2003) in bovine, (Bard, 2008, Akhter et al., 2012) in Buffalo, (Reed et al., 2009) in human and (Gilab et al., 2003) in ram semen. The use of Bioxcell and the Biociphos extenders (soy extract diluents commercial brand; IMV, France) in buffalo bull semen significantly increased the post-thaw sperm motility and the viability index com- 
pared to semen extended in the Tris-egg yolk extender (Bard, 2008).

The same trend was reported by Gilab et al. (2003) who indicated that the subjective motility evaluation was slightly higher in Bioexcell than that in the milk extender in ram frozen semen. In human semen, no significant differences were observed between before and after cryopreservation in media supplemented with egg yolk or soy lecithin for recovery of sperm motility, sperm cell morphology and maintenance of sperm DNA integrity in vitro (Reed et al., 2009). Both egg yolk and soybean milk contain phospholipids, which protect spermatozoa during cold shock.

Freeze-thawing processes impair the plasma membrane functions of buffalo bull spermatozoa (Anzar et al., 2010; El-Keraby et al., 2013). The damage to biomembrane system that mostly occurs during cryopreservation reduced sperm motility and fertilizing ability of frozen-thawed spermatozoa (Ansari et al., 2010). Post-thaw percentage of sperm with intact plasma membrane was higher in $15 \%$ soybean milk extender compared with control and other levels of TSM.

In similar studies on prepared extenders containing soya-lecithin, higher plasma membrane integrity of bovine semen was reported in AndroMed (Aires et al., 2003), Biociphos Plus (Gil et al., 2000; Amirat et al., 2004 and 2005) and Bioxcell (Gil et al., 2002 and Stradaioli et al., 2007) compared with egg yolk-based extenders. However, in buffalo, Bioxcell did not improve plasma membrane integrity of spermatozoa (Akhter et al., 2010). Khalifa et al. (2014) found that soybean lecithin could be able to increase proportions of viable frozenthawed of ram spermatozoa which reflected positively on fertility rates.

In goat, Roof et al., 2011 concluded that a commercially available soy-based extender was superior to an egg yolk-based extender in preserving motility of cryopreserved goat sperm, using a two steps method, also, the extender containing soybean lecithin and low glycerol provided the best motility and viability of chilled-stored spermatozoa and preserved their fertilization capacity (Yotov, 2015).

In the present study, the post-thaw sperm viability was superior in 15\% soybean milk extender compared with control or other TSM extenders. It is noteworthy to mention that HDLs of egg yolk interact with bovine seminal plasma proteins and accelerate the sperm capacitation, while the LDLs interact with seminal plasma proteins (Manjunath et al., 2002), decrease the efflux of cholesterol and phospholipids from the spermatozoa membrane and prevent premature capacitation and subsequent acrosome reaction (Bergeron et al., 2004). It is to believe that HDLs in egg yolk are responsible for capacitation and simultaneous acrosome reaction (Anton et al., 2003).

Amirat et al. (2005) also recorded the highest sperm numbers with functionally intact acrosomes cryopreserved in soya-lecithin-based extender like Biociphos Plus as compared to an egg yolk-based extender like Triladyl. Bioxcell is the only soya-lecithin-based extender evaluated for freezability and fertility of buffalo bull semen and found similar to tris-citric acid egg yolk extender in fertility rate (Akhter et al., 2010).

It is concluded that $15 \%$ soybean milk-based extender is suitable alternative to egg yolk-based extender for cryopreservation of buck semen and improves semen freezability.

\section{AUTHOR CONTRIBUTIONS}

1) Study conception and design: W. SOLTAN; E. ELSIEFY; I. ABD EL-RAZEK and I. EL-SHAMAA

2) Acquisition of data: W. SOLTAN; E. EL-SIEFY; I. ABD EL-RAZEK and I. EL-SHAMAA

3) Analysis and interpretation of data: I. ABD ELRAZEK; M. EL-SHARAWY; K. KUBOTA; N. YAMAUCHI and I. EL-SHAMAA

4) Drafting of manuscript: W. SOLTAN; E. EL-SIEFY; M. EL-SHARAWY; K. KUBOTA; N. YAMAUCHI and I. EL-SHAMAA

5) Critical revision: M. EL-SHARAWY; K. KUBOTA; N. YAMAUCHI and I. EL-SHAMAA.

\section{REFERENCES}

Aires, V. A.; K. D. Hinsch; F. Müller-Schlösser; K. Bogner; S. Müller-Schlösser and E. Hinsch 2003 In vitro and in vivo comparison of egg yolk-based and soybean lecithin-based extenders for cryopreservation of bovine semen. Theriogenology, 60: 269-279

Akhter, S.; M. S. Ansari; B. A. Rakha; S. M. H. Andrab; S. Iqbal and N. Ullah 2010 Cryopreservation of buffalo (Bubalus bubalis) semen in Bioxcell extender. Theriogenology., 74: 951-955

Akhter, S.; M. S. Ansari; S. M. H. Andrab; B. A. Rakha; N. Ullah and M. Khalid 2012 Soya-lecithin in extender improves the freezability and fertility of buffalo (Bubalus bubalis) bull spermatozoa. Reprod. Dom. Anim., 47: 815-819

Amirat, L.; D. Tainturier; L. Jeannaau; C. Thorin; O. Gerard; J. L. Counters and M. Anton 2004 Bull semen in vitro fertility after cryopreservation using egg yolk LDL: a comparison with Optidyl, a commercial egg yolk extender. Theriogenology, $\mathbf{6 1}$ : 895-907

Amirat, L.; M. Anton; D. Tainturier, G. R. Chatagnon; I. Battut and J. L. Courtens 2005 Modifications of bull spermatozoa induced by three extenders: biociphos, low density lipoprotein and Triladyl, before, during and after freezing and thawing. Reprod., 129: 535-543

Andrabi, S. M. H.; M. S. Ansari, N. Ullah; M. Anwar; A. Mehmood and S. Akhter 2008 Duck egg yolk in extender improves the freezability of buffalo bull spermatozoa. Anim. Reprod. Sci., 104 $427-433$

Ansari, M. S.; B. A. Rakha; S. M. H. Andrabi and S. Akhter 2010 Usefulness of powdered and fresh egg yolk for cryopreservation of Zebu bull spermatozoa. Reprod. Biol., 10: 235-240

Ansari, M. S.; B. A. Rakha; N. Ullah; S. M. H. Andrabi, and S. Akhter 2013 Glutathione addition in Tris-citric egg yolk extender improves the quality of cooled buffalo (Bubalus bubalus) bull semen. Pakistan J. Zool., 43: 49-55

Anton, M.; V. Martinet; M. Dalgalarrodo; V. Beaumal; E. DavidBriand and H. Rabesona 2003 Chemical and structural characterization of low-density lipoproteins purified from hen egg yolk. Food Chem., 83: 175-183

Anzar, M.; Z. Rasul; T. A. Ahmed and N. Ahmad 2010 Response of buffalo spermatozoa to low temperatures during cryopreservation. Reprod. Fertil. Dev., 22: 871-880

Bard, M. R. 2008 Cryopreservation of Buffalo spermatozoa in soy lecithin based extender. Assiut Vet. Med. J., 54: 272-284 
Bergeron, A.; M. H. Crete and P. Manjunath 2004 Low-density lipoproteins fraction from hen's egg yolk decreases the binding of the major proteins of bovine seminal plasma to sperm and prevents lipid efflux from the sperm membrane. Biol. Reprod., 70: $708-717$

Bousseau, O. S.; J. P. Brillard; B. Marquant-le Guienne; B. Guerin, A. Camus and M. Lechat 1998 Comparison of bacteriological qualities of various egg yolk sources and the in vitro and in vivo fertilizing potential of bovine semen frozen in egg yolk or lecithin based diluents. Theriogenology, 50: 699-706

Duncan, D. B. 1955 Multiple Range and Multiple F. Test Biometrics, 11: 1-42

El-Keraby, F. E.; K. T. Osman; H. B. Ganah and E. M. El-Siefy 2010 Soymilk-based extender for cryopreservation of bovine semen. J. Anim. And Poultry Prod., 1(2): 61-69

El-Keraby, F. E.; E. M. E. El-Siefy and A. M. A. Hussein 2013 Soybean milk-based extender for cryopreservation of Egyptian buffalo bulls semen. Proceeding of the $4^{\text {th }}$ scientific conference of Anim. Prod. Res. Inst., 27-32

El-Sharawy M. E., I. S. El-Shamaa, M. A. R. Ibrahim and M. E. ElSeify 2012a Using of low density lipoproteins and glutamine to improve frozen buffalo bull semen and fertility. Reprod. Domest. Anim., 47: 444 (Abstract)

El-Sharawy M. E., I. S. El-Shamaa, M. A. R. Ibrahim, I. M. Abd ElRazek and E. M. El-Seify 2012b Effect of low density lipoproteins in extender on freezability and fertility of Egyptian Buffalo bull semen. Scientific paper, Animal Science Series D, Vol. (LV): 114-120

El-Siefy, E. M. 2014 Effect of addition different levels of soybean milk to tris diluent on the freezability and fertility of Holstein bulls semen. Kafrelsheikh, Vet. Med. J. 12: 225-243

Gilab, J.; M. Rodriguez-Irazoqui; N. Lundeheim; L. Soderquist and H. Rodriguez-Martinez 2003 Fertility of ram semen frozen in Bioexcell ${ }^{\circledR}$ and used for cervical artificial insemination. Theriogenology., 59: 1157-1170

Gil, J.; A. Januskausks; M. C. Haard; M. G. M. Haard; A. Johanisson; L. Soderquist and H. Rodriguez-Martinez 2000 Functional sperm parameters and fertility of bull semen extended in Biociphos Plus. Reprod. Domest. Anim., 35: 69-77

Gil, J.; M. Rodriguez-Irazoqui; L. Soderquist and H. RodriguezMartinez 2002 Influence of centrifugation or low extension rates prefreezing on the fertility of ram semen after cervical insemination. Theriogenology, 57: 1781-1792

Gil, J.; M. Rodriguez-Irazoqui; M., Lundeheim, N., Söderquist, L. and H. Rodríguez-Martínez 2003 Fertility of ram semen frozen in Bioexcell and used for cervical artificial insemination. Theriogenology, 59: 1157-1170

Hancock, J. I. 1951 A staining technique for the study of temperature shock in semen. Nature, Lond., pp, 167: 223

Jeyendran, R. S.; H. H. Van Der Ven; M. Perez-Pelaez; B. G. Crabo and L. J. D. Zaneveled 1984 Development of an assay to assess the functional integrity of the human sperm membrane and its relationship to other semen characteristics. J. Reprod. Fertil., 70: 219-228

Kasimanickam, R.; V. Kasimanickam; A. Tibracy, and K. Pelzer 2011 Effect of semen extenders on sperm parameters of ram semen during liquid storage at $4^{\circ} \mathrm{C}$. Small Rum. Res., 99: 208-213

Khalifa, E. I. and M. A. M. Abdel-Hafez 2014 Effect of soybean lecithin-based semen extender on freezability and fertility of Rahmani ram spermatozoa. Egyptian Journal of Sheep \& Goat Sciences, 9(1): 59-66

Khan, R. U.; Rahman, Z. U.; Javed, I. and F. Muhammad 2012
Effect of vitamins, probiotics and protein on semen traits in post-molt male broiler breeders. Anim. Reprod. Sci., 135: $85-90$

Leboeuf, B.; Restall, B. and S. Salamon, 2000 Production and storage of goat semen for artificial insemination. Anim. Reprod. Sci., 62: 113-141

Manjunath, P.; V. Nauc; A. Bergeron and M. Menard 2002 Major proteins of bovine seminal plasma bind to the low-density lipoprotein fraction of hen's egg yolk. Biol. Reprod., 67: 1250-1258

Melrose, D. R. and J. A. Laing 1970 The characteristics of normal semen. ed. By J. A. laing Bailliere tindall and cassel. London.

Moustacas, V. S.; F. G. Zaffalon; M. A. Lagares; A. M. LoaizaEccheverri; F. C. Varago; M. M. Neves; L. G. D. Heneine; R. P. Arruda and M. Henry 2011 Natural, but not lyophilized, low density lipoproteins were an acceptable alternative to egg yolk for cryopreservation of ram semen. Theriogenology, $\mathbf{7 5}$ 300-307

Moussa, M.; V. Matinet; A. Trimeche; D. Tain-turier and M. Anton 2002 Low density lipoproteins extracted from hen egg yolk by an easy method: cryoprotective effect on frozen-thawed bull semen. Theriogenology, 57: 695-706

Reed, M. L.; P. C. Ezeh; A. Hamic; D. J. Thomson and C. L. Caperton 2009 Soy lecithin replace egg yolk for cryopreservation of human sperm without adversely affecting posthawed motility, morphology, sperm DNA integrity or sperm binding to hyaluronate. J. Fert. Ster., 92: 1787-1790

Rehman, F. U.; M. S. Qureshi and R. U. Khan 2014 Effect of soybean based extenders on sperm parameters of HolsteinFriesian bull during liquid storage at $4^{\circ} \mathrm{C}$. Pakistan J. Zool., 46: $185-189$

Roof, D. J., S. Bowley, L. L. Price and D. J. Matsas 2012 Comparison of two commercial extenders for cryopreservation of goat semen without sperm washing. Theriogenology, $\mathbf{7 7}$ : $412-420$

Salisbury, G. W.; N. L. Van Demark and J. R. Lodge 1978 Physiology of Reproduction and AI of cattle. H. freeman and Comp. San Francisco. U.S.A.

Singh, A. K., V. K. Singh, B. M. Narwade, T. K. Mohanty, and S. K. Atreja 2012 Comparative quality assessment of buffalo (Bubalus bubalis) semen chilled $\left(5^{\circ} \mathrm{C}\right)$ in egg yolk- and soya milk-based extenders. Reprod. Domest. Anim., 47: 596-600

Steel, R. G. D.; J. H. Torrie, and D.A. Dieky 1997 Principles and procedures of statistics. 3rd ed. McGraw Hill Book Co. Inc. New York.

Stradaioli, G.; T. Noro; L. Sylla and M. Monaci 2007 Decrease in glutathione (GSH) content in bovine sperm after cryopreservation: comparison between two extenders. Anim. Reprod. Sci., 67: 1249-1255

Thun, R.; M. Hurtato and F. Janett 2002 Comparison of Biociphos-Plus and Tris-Egg yolk extender for cryopreservation of bull semen. Theriogenology, 57: 1087-1094

Van Wagtendonk-Leeuw A. M.; R. M. Haring; L. M. KaalLandsbergen and J. H. den Daas 2000 Fertility results using bovine semen cryopreserved with extenders based on egg yolk and soybean extract. Theriogenology, 54: 57-67

Watson, P. F. 1975 Use of a Giemsa stain to detect changes in acrosomes of frozen ram spermatozoa. Vet. Res., 97: 12-15

Yotov, S. 2015 Effect of TFC-based extenders with soybean lecithin and/or low concentration of glycerol on the quality of goat chilled-stored semen. Int. Curr. Microbiol. App. Sci., 4 $752-761$ 